\title{
The Influence of Oxisol Physics Parameters on Dry Matter Production in Grasses of Brachiaria Genus
}

\author{
Pedro Luan Ferreira da Silva (Corresponding author) \\ Department of Soil and Rural Engineering, Federal University of Paraíba \\ Zip code: 58397.000, Areia, Paraíba, Brazil
}

Tel: 55-83-9-98699512_E-mail: pedroluanferreira@gmail.com

\author{
Flávio Pereira de Oiveira \\ Department of Soil and Rural Engineering, Federal University of Paraíba \\ Zip code: 58397.000, Areia, Paraíba, Brazil \\ E-mail: pereira@cca.ufpb.br
Walter Esfrain Pereira
Department of Fundamental and Social Sciences, Federal University of Paraíba
Zip code: 58397.000, Areia, Paraíba, Brazil
E-mail: walterufpb@yahoo.com.br
Adriana Ferreira Martins
Department of Soil and Rural Engineering, Federal University of Paraíba
Zip code: 58397.000, Areia, Paraíba, Brazil
E-mail: biol.adriana@gmail.com

Camila Costa da Nóbrega

Department of Soil and Rural Engineering, Federal University of Paraíba

Zip code: 58397.000, Areia, Paraíba, Brazil

E-mail: camila_cnobrega@hotmail.com 
Danillo Dutra Tavares

Department of Agronomy, Federal Rural University of Pernambuco

Zip code: 52171-900, Recife, Pernambuco, Brazil

E-mail: danilodutrat@hotmail.com

\author{
Igor Gabriel dos Santos Oliveira Botelho \\ Department of Soil and Rural Engineering, Federal University of Paraíba \\ Zip code: 58397.000, Areia, Paraíba, Brazil \\ E-mail: igoroliveiratoic@gmail.com
}

\begin{abstract}
Alison José da Silva
Department of Soil and Rural Engineering, Federal University of Paraíba

Zip code: 58397.000, Areia, Paraíba, Brazil

E-mail: alisonjose1997@gmail.com
\end{abstract}

\begin{abstract}
Tales Emanuel Duarte Santos
Department of Soil Science, Federal University of Lavras

Zip code: 37200-000, Lavras, Minas Gerais, Brazil
\end{abstract}

E-mail: taleesss@gmail.com

Received: Nov. 3, 2019

doi:10.5296/jas.v8i2.15749
Accepted: Dec. 18, 2019 Published: Jan. 3, 2020

URL: https://doi.org/10.5296/jas.v8i2.15749

\begin{abstract}
The aim of this study was to assess the correlation between physical attributes of a Yellow Oxisol and the shoot dry matter production in grasses from the Brachiaria genus in the Brejo region, in Paraíba. The experiment has been conducted since 2005 in an experimental area of the Center of Agricultural Sciences of the Federal University of Paraíba, Areia-PB (6 $58^{\circ} 12^{\prime \prime}$ $\mathrm{S} ; 35^{\circ} 41^{\prime} 15^{\prime \prime} \mathrm{W}$ and $573 \mathrm{~m}$ altitude). The experimental design adopted was that of randomized complete blocks (RCB) with 4 treatments and 4 replications. T1- Brachiaria decumbens Stapf.; T2- Brachiaria brizantha (Hochst) Stapf.; T3- Brachiaria humidicola (Rendle) Schwnickerdt Vr.; T4- Brachiaria brizantha MG5 cv. Vitória. The soil in the
\end{abstract}


experimental area was characterized as Dystrophic Yellow Oxisol with clay-sandy texture. Soil samples with disturbed and undisturbed structure were collected within the $0.0-0.10 \mathrm{~m}$ layer. The shoot dry matter of grasses was collected in october of 2018. The analyzed variables were: bulk density (BD), compaction degree (CD), total porosity (TP), macroporosity $(\mathrm{Ma})$, microporosity $(\mathrm{Mi})$, field capacity $\left(\theta_{\mathrm{FC}}\right)$, permanent wilting point $\left(\theta_{\mathrm{PWP}}\right)$, available water content $\left(\theta_{\mathrm{AWC}}\right)$, soil aeration capacity (SAC), mean weighted diameter of wet and dry aggregates (Wet and Dry MWD), aggregate stability index (ASI) and saturated hydraulic conductivity $\left(\mathrm{K}_{\theta}\right)$. The Student's t-test and Pearson's correlation analysis $(\mathrm{p}<0.05)$ were performed. It was concluded that dry matter production was positively influenced by $\theta_{\mathrm{FC}}$ and $\theta_{\mathrm{PWP}}$. And the increase of the average values of BD, CD, Wet and Dry MWD favored the increase of shoot dry matter production by grasses.

Keywords: Agreste of Paraíba, Poaceae, leaf area, soil physical quality, correlation

\section{Introduction}

Cattle is one of the main sources of profit for Brazil, considered a job and revenue promoter, for its strong participation in the national and international economic scenario. In total, there are 221.1 million animals spread in 190 million hectares of pastures, both natural and cultivated (ABIEC, 2018). It is an activity with low production costs as it demands no big investments and is possible to be executed with low use of agricultural implements, when compared to other activities, such as agriculture (Ferreira; Ferreira Neto, 2018).

However, the reduced usage of agricultural implements in the pastures involves issues that can greatly impact the animal production, especially when combined with the increasing soil degradation, leading to losses that significantly reduce the productivity of such activity (Dias Filho, 2014), apart from compromising the environmental sustainability (Silva et al., 2017a; Nascimento et al., 2019). Estimations show that $50 \%$ of Brazilian pastures are degraded, these are 95 million hectares which are located mainly in the North, Northeast and Central-West part of the country (Dias Filho, 2014).

The lack of soil maintenance and the loss of productivity are key-factors in the degradation of pastures, which combined to intense animal trampling unleash physical processes that make this activity less and less competitive (Macedo et al. 2000; Silva et al. 2011a). Soil compaction in one of the most common and least desired among physical processes within a pasture, because it involves mechanisms that lead to negative alterations in soil structure, with higher density and compaction degree, reduction of total porosity and rate of water infiltration (Lima et al., 2013). The impact in the soil may compromise the growth of grasses, as a result of a mechanical barrier caused by compacted layers, resulting in a smaller portion of soil being explored by the roots and consequently less water and nutrients absortion by the plants (Richart et al., 2005).

The negative effects of changes in the physical attributes of the soil on plant development are well known and find back up on scientific literature, especially related to soil compaction. Among the effects, are reductions in roots density, specific surface and dry mass (Leonel et al. (2007), reduction in roots mean diameter and impediment to root growth (Mazurana et al., 


\section{Macrothink}

2013; Valadão et al., 2015), leaf area reduction (Foloni et al., 2003), reduction in plant's height and lower aerial biomass production (Santos et al., 2013; Labegalini et al., 2016; Rosa et al., 2019) and lower levels of N, P, Ca and Mg in leaves (Valadão et al., 2017).

Grasses from Brachiaria genus have been used in pastures for being adaptable to the different edaphoclimatic conditions of Brazil. However, it is still unknown to which extent variations in the physical attributes of the soil may compromise its growth, especially concerning shoot dry matter production under the edaphic conditions of the Brejo microregion in Paraíba. It is noted a necessity for studies, especially in the long run, aiming to evaluate the correlation between physical attributes of the soil and the productive characteristics of the Brachiaria genus, as literature lacks information on this topic.

Therefore, it was aimed in this study to evaluate the linear correlation between physical attributes of a yellow oxisol and the shoot dry matter production of grasses belonging to the Brachiaria genus, in the microregion of Brejo in Paraíba.

\section{Material and Methods}

\subsection{Characterization of the Experimental Area}

The experiment has been conducted since 2005 in experimental area of the Center of Agricultural Sciences of the Federal University of Paraíba, in Areia (PB). The city is located within the Brejo microregion and in the Agreste of Paraíba mesoregion (6 $6^{\circ} 8^{\prime} 12^{\prime \prime} \mathrm{S}$; $35^{\circ} 41^{\prime} 15^{\prime \prime} \mathrm{W}$ and $620 \mathrm{~m}$ of altitude).

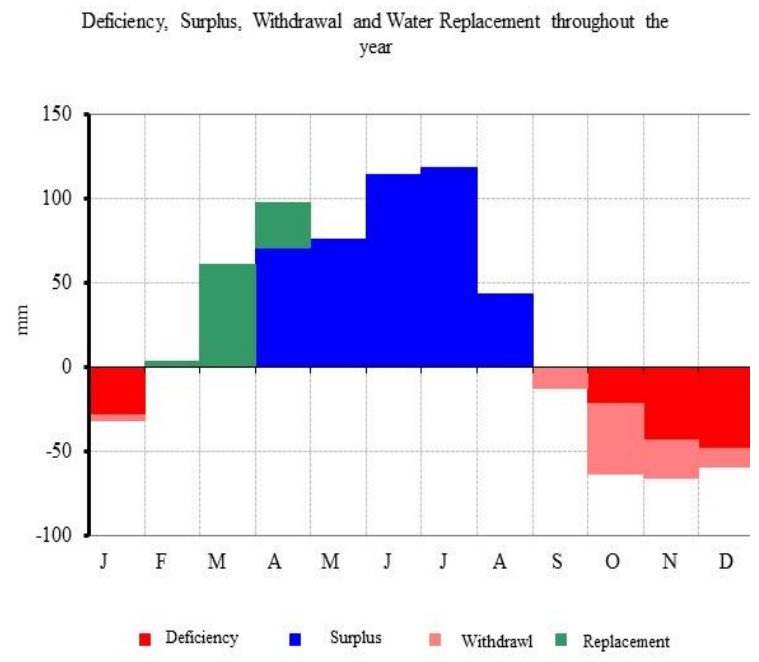

(a)

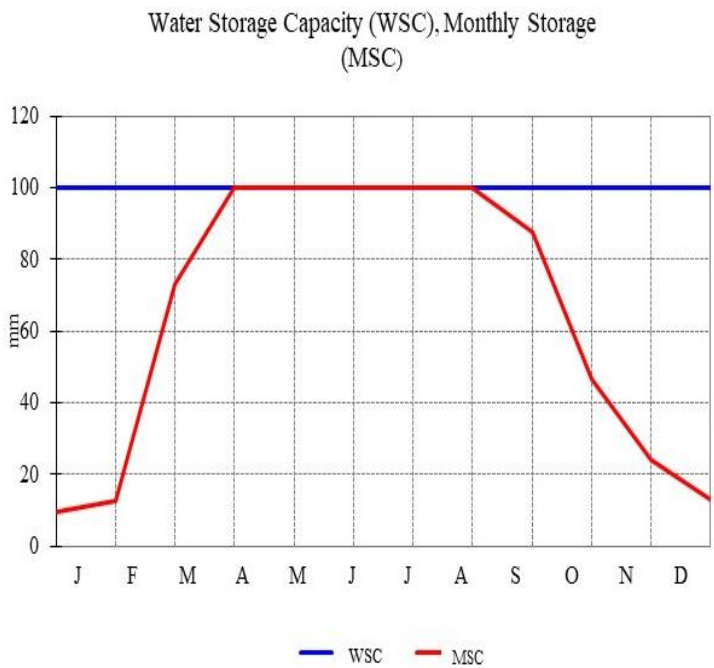

(b)

Figure 1. Soil water balance and water storage capacity for 2018, Areia-PB 
According to Köppen classification, the predominant climate in the municipality is As' tropical, hot and humid, with rains during autumn and winter and mean annual precipitation of $1400 \mathrm{~mm}$ (Almeida et al., 2014). The annual mea

$\mathrm{n}$ temperature is $24.5^{\circ} \mathrm{C}$ and the relative humidity of the air in average of $\mathrm{RH}$ is $80.0 \%$; as for the rain season, 62\% occurs between April and July (Lima et al., 2014). Soil water balance and water storage capacity for the January-December period of 2018 are shown in Figure 1, according to methodology proposed by (Rolim et al., 1998).

The soil in the experimental area was characterized as Dystrophic Yellow Oxisol with clay-sandy texture (Santos et al., 2018). In table 1, the physical characterization of the soil of the experimental area is presented.

Table 1. Soil physical characterization of the experimental area, in the $0.00-0.10 \mathrm{~m}$ layer under grasses

\begin{tabular}{ccccccccc}
\hline Layer & Sand & Silt & Clay & CDW & FD & PD & BD & TP \\
\hline$--\mathrm{m} \mathrm{--}$ & $--------------------\mathrm{g} \mathrm{kg}^{-1}$ & & & $----\mathrm{g} \mathrm{cm}^{-3}$ & & $\mathrm{~m}^{3} \mathrm{~m}^{-3}$ \\
$0.00-0.10$ & 574 & 69 & 357 & 14 & 961 & 2.58 & 1.22 & 0.50 \\
\hline
\end{tabular}

$\mathrm{PD}=$ Particle density, $\mathrm{BD}=$ Bulk density, $\mathrm{TP}=$ Total porosity, $\mathrm{FD}=$ Flocculation Degree $\mathrm{CDW}=$ Clay dispersed in water

As for the chemical characterization of the experimental area's soil, the analysis determine the following values: $\mathrm{pH}=5.3\left(\mathrm{H}_{2} \mathrm{O} 1: 2.5\right) ; \mathrm{Ca}^{2+}=1.89 \mathrm{cmol}_{\mathrm{c}} \mathrm{dm}^{-3}, \mathrm{Mg}^{2+}=1.43 \mathrm{cmol}_{\mathrm{c}} \mathrm{dm}^{-3}$, $\mathrm{Al}^{3+}=0.30 \mathrm{cmol}_{\mathrm{c}} \mathrm{dm}^{-3}, \mathrm{H}+\mathrm{Al}^{3+}=8.33 \mathrm{cmol}_{\mathrm{c}} \mathrm{dm}^{-3}, \mathrm{SB}=3.46 \mathrm{cmol}_{\mathrm{c}} \mathrm{dm}^{-3}, \mathrm{CEC}=11.79 \mathrm{cmol}_{\mathrm{c}}$ $\mathrm{dm}^{-3}, \mathrm{Na}^{+}=0.06 \mathrm{cmol}_{\mathrm{c}} \mathrm{dm}^{-3} ; \mathrm{SOM}=49.52 \mathrm{~g} \mathrm{~kg}^{-1} ; \mathrm{P}=1.82 \mathrm{mg} \mathrm{dm}^{-3} \mathrm{e} \mathrm{K}^{+}=28.37 \mathrm{mg} \mathrm{dm}^{-3}$.

\subsection{Experimental Design and Characterization of Analyzed Variables}

The experimental design adopted was that of randomized complete blocks (RCB) with 4 treatments and 4 replications $(4 \times 4)$. The assessed treatments were the following: T1Brachiaria decumbens Stapf.; T2- Brachiaria brizantha (Hochst) Stapf.; T3- Brachiaria humidicola (Rendle) Schwnickerdt Vr.; T4- Brachiaria brizantha MG5 cv. Vitória.

The grasses were planted in 2005 in experimental plots measuring $10 \times 5 \mathrm{~m}$, therefore $50 \mathrm{~m}^{2}$ of usable area; plots were one meter apart and blocks were two meters apart. Characterization relating growth habit and shoot dry matter production of grasses are presented in Table 2. 
Table 2. Growth habits and shoot dry matter production of Brachiaria genus grasses

Grasses

Growth habit

Dry matter production

\begin{tabular}{lcc}
\hline Brachiaria decumbens & Decumbent & $1.55^{* *}$ \\
Brachiaria brizantha & Caespitose & $3.38^{* *}$ \\
Brachiaria humidicola & Stoloniferous & $1.37^{* *}$ \\
B. brizantha MG-5 Vitória & Caespitose & $2.38^{* *}$ \\
\hline
\end{tabular}

**Results obtained by Silva et al. (2019), in the experimental area under dry farming system.

In the year of implantation (2005), $553 \mathrm{~kg} \mathrm{ha}^{-1}$ of NPK mixture (60-80-45) was fertilized in the experimental plots, with the following nutrient sources: ammonium sulfate $\left(\mathrm{NH}_{4}\right)_{2} \mathrm{SO}_{4}$, triple superphosphate $\mathrm{P}_{2} \mathrm{O}_{5}$ and potassium chloride $\mathrm{KCl}$. The fertilizer was sowed at the beginning of the rain season, just after pruning and standardizing the grasses, repeating the process until 2010 (Almeida et al., 2014). After that the experiment was conducted annually but with no fertilizer addition.

\subsubsection{Determination of Shoot Dry Matter of Grasses}

The shoot dry matter samples were collected in November 2018 at three random spots in the experimental plots, adding up to 48 sampled points (12 points per treatments, 4 points per plot) using a wooden template measuring $0.30 \times 0.21 \mathrm{~m}\left(0.063 \mathrm{~m}^{2}\right)$. Subsequently, the samples were put to dry in an air cycling oven at $\pm 65^{\circ} \mathrm{C}$ for 72 hours until constant weight was reached. Finally, the samples were weighed in analytical scale to determine the shoot dry matter $\left(\mathrm{kg} \mathrm{ha}^{-1}\right)$.

\subsubsection{Soil Sampling for Traits Analysis and Determination}

The undisturbed soil samples used to determine the physical attributes of the soil were collected using an Uhland sampler, $0.05 \mathrm{~m}$ high and $0.05 \mathrm{~m}$ diameter $\left(98.17 \mathrm{~cm}^{3}\right)$ at the center of each experimental plot. Then, the samples were sent to analysis to the Laboratory of Soil Physical Analysis of the Federal University of Paraíba. For the determination of the mean weighted diameter of wet and dry aggregates, soil samples of preserved structure were collected, using straight shovel, for subsequent breaking and sieve screening for aggregates separation (9.52 $\mathrm{mm}$ mesh).

The analyzed variables were: bulk density (BD), compaction degree (CD), total porosity (TP), macroporosity $(\mathrm{Ma})$, microporosity $(\mathrm{Mi})$, field capacity $\left(\theta_{\mathrm{FC}}\right)$, permanent wilting point $\left(\theta_{\mathrm{PWP}}\right)$, available water content $\left(\theta_{\mathrm{AWC}}\right)$, soil aeration capacity (SAC), mean weighted diameter of wet and dry aggregates (Wet MWD and Dry MWD), aggregate stability index (ASI) and saturated hydraulic conductivity $\left(\mathrm{K}_{\theta}\right)$. 
Bulk density (BD) was determined by the ratio between dry soil mass/ soil sample volume, according to the methodology proposed by Blake \& Hartge (1986). Thus, it was possible to calculate the compaction degree of the soil (Equation 1), defining the percentage of soil compaction in relation to its maximum, using $1.85 \mathrm{~g} \mathrm{~cm}^{-3}$ as the maximum restrictive value of BD for a medium texture Oxisol (Suzuki et al., 2007).

$$
\mathrm{CD}=(B D / 1.85 * 100)
$$

Where: $\mathrm{CD}$ is the compaction degree and BD is the bulk density. Total porosity (TP) was determined by the humidity corresponding to the soil saturation volume, as described in the equation (2):

$$
\mathrm{TP}=(\mathrm{MSS}-\mathrm{Mds}) / \mathrm{CV}
$$

Where: TP is the total porosity of the soil $\left(\mathrm{m}^{3} \mathrm{~m}^{-3}\right)$, MSS is the mass of saturated soil, Mds is the mass of dry soil and CV is the cylinder volume. Microporosity (Mi) was determined in a tension table by applying the $-6 \mathrm{kPa}$ potential in saturated soil samples, as suggested by Teixeira et al. (2017). Macroporosity (Ma) was obtained through the difference between (TP $-\mathrm{Mi})$.

Soil Aeration Capacity was determined following methodology proposed by Reynolds et al. (2007). Matrix potentials of $\Psi_{\mathrm{m}}-10 \mathrm{kPa}$ and $-1500 \mathrm{kPa}$ were used to determine humidity in the field capacity $\left(\theta_{\mathrm{FC}}\right)$ and the permanent wilting point $\left(\theta_{\mathrm{PWP}}\right)$, as described in Teixeira et al. (2017). Through the relation $\left(\theta_{\mathrm{FC}}-\theta_{\mathrm{PWP}}\right)$, the available water content for plants was obtained $\left(\theta_{\mathrm{AWC}}-\mathrm{m}^{3} \mathrm{~m}^{-3}\right)$.

Saturated hydraulic conductivity $\left(\mathrm{K}_{\theta}-\mathrm{cm} \mathrm{h}^{-1}\right)$, was determined in undisturbed soil samples, using permeameter of constant charge and calculated through the following equation:

$$
\left(\mathrm{K}_{\theta}\right)=\mathrm{Q} \times \mathrm{L} / \mathrm{A} \times \mathrm{H} \times \mathrm{T}
$$

Where: $\left(\mathrm{K}_{\theta}\right)$ - is the saturated hydraulic conductivity $\left(\mathrm{cm} \mathrm{h}^{-1}\right), \mathrm{Q}-$ is the water volume percolated and colected in a measuring cylinder $\left(\mathrm{mL}^{-1}\right), \mathrm{L}-$ is the soil block height $(\mathrm{cm}), \mathrm{A}-$ is the cylinder area $\left(\mathrm{cm}^{2}\right), \mathrm{H}$ - is the height of the soil block + water sheet $(\mathrm{cm})$ and $\mathrm{T}-$ is the time in hours of percolated water volume collection.

The determination of the mean weighted diameter of wet aggregates (Wet MWD) and mean weighted diameter of dry aggregates (Dry MWD) were performed according to methodology proposed by Kemper \& Chepil (1965), with variations proposed by Carpenedo \& Mielniczuk (1990) and Silva \& Mielniczuk (1997), where the principle is to evaluate the resistance offered by the aggregates when submitted to oscillations in both wet and dry sieves. The aggregate stability index (ASI) was calculated through the Wet/Dry MWD ratio.

The clay dispersed in water was obtained by granulometric analysis of the soil, according to the densimeter method of Bouyoucos (Teixeira et al. 2017), but with no use of chemical dispersant. For the total clay, the previous procedure was performed, however using sodium hydroxide $(\mathrm{NaOH}-1 \mathrm{~N})$ as a dispersant agent and mechanical agitation as physical dispersant. The flocculation degree was obtained according to the following: 


$$
\mathrm{FD}=\text { Clay-CDW/ Clay*1000 }
$$

Where: FD is the flocculation degree of the soil $\left(\mathrm{g} \mathrm{kg}^{-1}\right)$, Clay is the clay content dispersed in sodium hydroxide $-\mathrm{NaOH}\left(\mathrm{g} \mathrm{kg}^{-1}\right)$, and $\mathrm{CDW}$ is the clay content dispersed in water $\left(\mathrm{g} \mathrm{kg}^{-1}\right)$.

\subsection{Statistical Analysis of Data}

The Student's t-test and the Pearson's correlation analysis were performed at $(p<0.05)$, using R statistical software (R DEVELOPMENT CORE TEAM, 2013).

\section{Results and Discussion}

Figure 2 shows the correlation data between bulk density (a) compaction degree (b), and shoot dry matter production (DMP) of Brachiaria grasses. Through the analysis of the images it is possible to state that there was no statistically significant variation between BD x DMP and CD $x \operatorname{DMP}(\mathrm{p}<0.05)$.
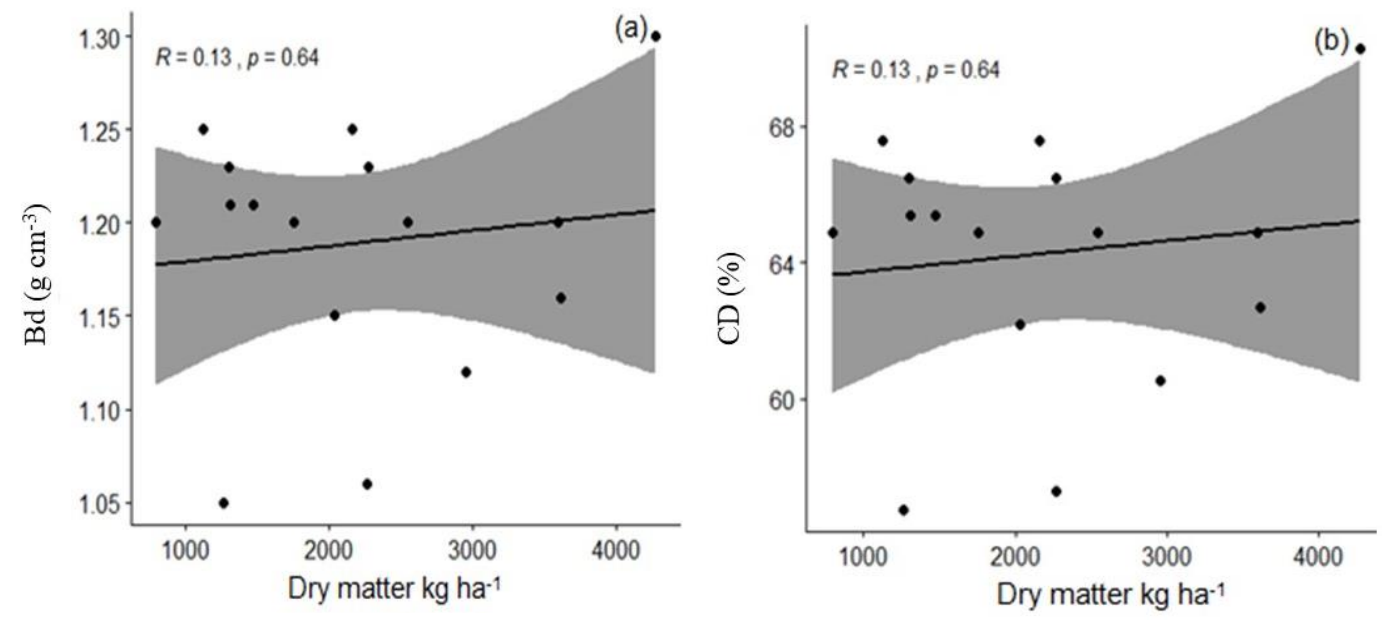

Figure 2. Linear correlation of bulk density (a) and compaction degree (b) with shoot dry matter production (DMP) in grasses of Brachiaria genus

Correlation values were low, with $R=0.13$ for $\mathrm{BD}$ x DMP and $R=0.13$ for CD x DMP. The mean values showed strong dispersion in relation to the straight line for both evaluated attributes, as a result of the spatial dependence of the $\mathrm{CD}$ to the mean values of BD. The dry matter production was not affected by the attributes, maintaining a slight growth trend as the average values of the attributes increased.

The result found in this study was different from that found by Vitória et al. (2012), working with linear and spatial correlation between Brachiaria brizantha productivity and soil physical attributes. They observed that soil density is inversely proportional to grass dry matter production, for density values ranging between 1.21 and $1.87 \mathrm{~g} \mathrm{~cm}^{-3}$.

The results observed in Figure 2 (a) and (b) show that density values of $1.05-1.30 \mathrm{~g} \mathrm{~cm}^{-3}$ and compaction degree values of $60.0-68.0 \%$ have no negative influence in shoot dry matter production. It is also observed that BD was within the limit range for medium texture Oxisols, which according to Reichert et al. (2007) is between 1.20 and $1.40 \mathrm{~g} \mathrm{~cm}^{-3}$. Therefore, it can be stated that the $\mathrm{BD}$ and $\mathrm{CD}$ values presented in Figure 2 do not restrain the development 
and productivity of grasses. Even with the increase in the mean value of these variables, dry matter yield tended to increase, exceeding the average of 4 tons per hectare for all four Brachiaria cultivars.

The linear correlation analysis between soil microporosity (Mi) and macroporosity (Ma) with shoot dry matter production (DMP) is shown in Figure 3 (a) MI x DMP and (b) Ma x DMP.
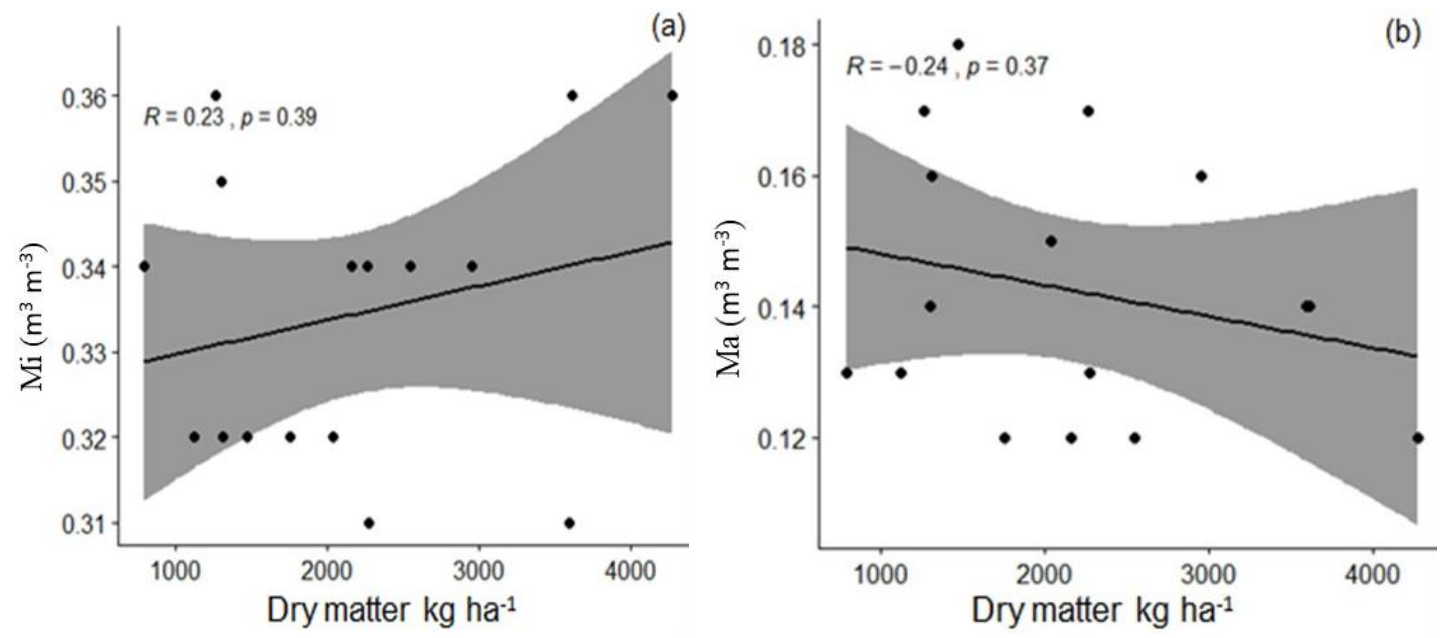

Figure 3. Linear correlation of microporosity (a) and macroporosity (b) with shoot dry matter production (DMP) in grasses of Brachiaria genus

There was no significant linear correlation ( $\mathrm{p}<0.05)$ between Mi x DMP $(p=0.39)$ and Ma $\mathrm{x}$ $\operatorname{DMP}(p=0.37)$. As for the correlation values, Figure 3 shows (a) $R=0.23$ for Mi $\mathrm{x}$ DMP and (b) $R=-0.24$ for Ma x DMP. Both $R$ values are considered weak, meaning they have little influence on dry matter production in grasses.

However, microporosity and macroporosity showed inverse linear trends, increasing for Mi x DMP and decreasing for Ma x DMP (Figure 2). These results emphasize that microporosity, despite its low correlation with dry matter production, does not affect grass yield. This statement is confirmed by Figure 3 (a), which shows the increase in DMP as a function of the increase in soil microporosity.

This result is due to the importance of microporosity for water availability to plants, since much of the water retained in the soil is present in the micropores. For Dexter et al. (2004) and Barros et al. (2016), the core function of micropores is to retain water and make it available for plants. The solubilization of nutrients also depends on the moisture level of the soil (micropores), which is where a large amount of essential nutrients for plant development is contained.

The reduction in shoot dry matter production as soil macroporosity increases (Figure $3 b$ ) is related to a rise in soil aeration capacity (SAC) and a decrease in the volume of retained water. This factor is evidenced by the weak, but negative correlation between Ma x DMP $(R=-0.24)$. The mean values of macroporosity were $0.16-0.18 \mathrm{~m}^{3} \mathrm{~m}^{-3}$ and the highest yield of dry matter production was found for $0.14-0.16 \mathrm{~m}^{3} \mathrm{~m}^{-3}$ (Figure $3 \mathrm{~b}$ ), with loss in DMP along time. From these results, we can draw that, for the soil condition dealt in this study, keeping macroporosity 
levels around $0.15 \mathrm{~m}^{3} \mathrm{~m}^{-3}$ is enough to achieve a good dry matter production for grasses of the Brachiaria genus.

Figure 4 (a) shows Pearson's linear correlation analysis between soil aeration capacity (SAC) and shoot dry matter production of Brachiaria grasses. In Figure 3 (b), the result of the linear correlation analysis between total porosity (TP) and dry matter production (DMP) is observed.
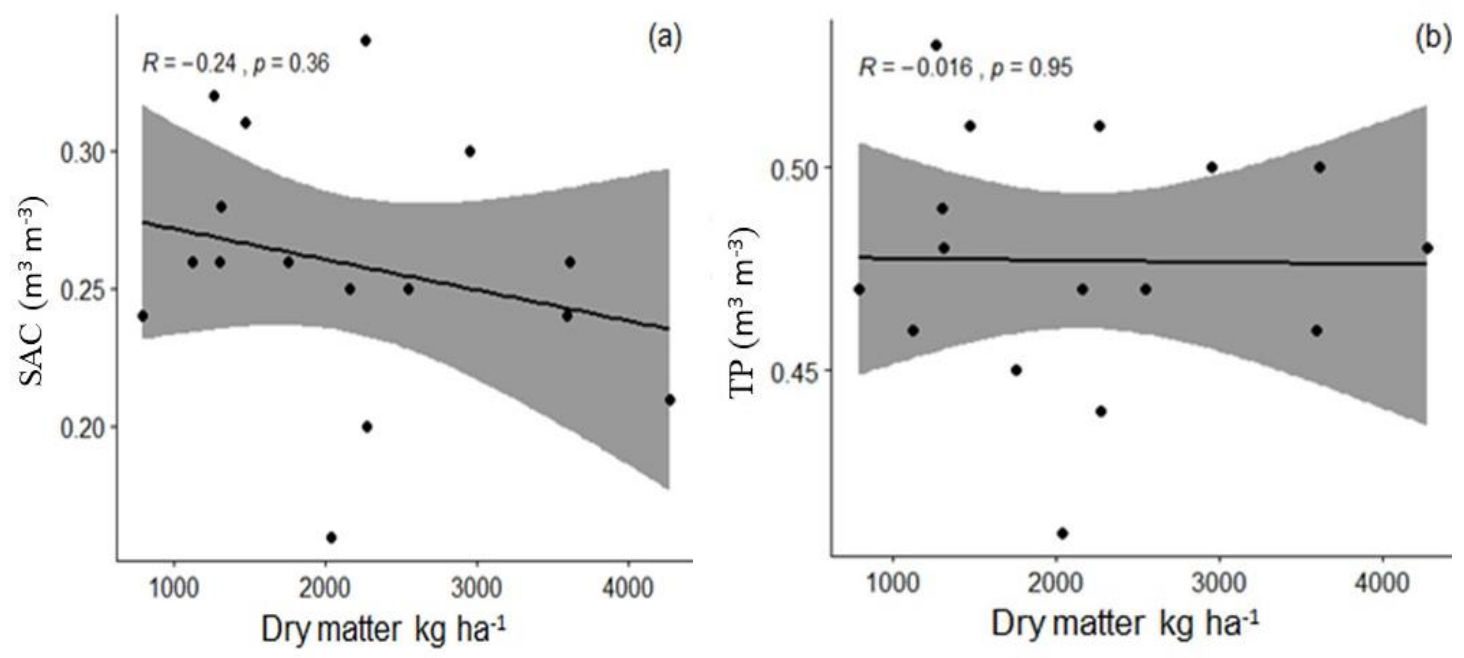

Figure 4. Linear correlation of soil aeration capacity (a) and total pososity (b) with shoot dry matter production (DMP) in grasses of Brachiaria genus

There is a weak negative correlation between SAC x DMP $(R=-0.24, p=0.36)$ and an almost nonexistent correlation between TP x DMP $(R=-0.016, p=0.95)$. Both correlations were not statistically significant. However, it is observed that there was a reduction in DMP with increasing soil aeration capacity, especially when the average SAC values exceeded the 0.30 $\mathrm{m}^{3} \mathrm{~m}^{-3}$ limit (Figure 4a).

This finding matches the data analysis verified by Reynolds et al. (2002), Tormena et al. (2002) and Assis et al. (2015). For them the SAC required for the proper development of plants should be in between 0.10 and $0.34 \mathrm{~m}^{3} \mathrm{~m}^{-3}$, because, below or above these limits, numerous damages to plants occur due to problems related to water retention in the soil and low gas diffusion around the rhizosphere.

In the case of grasses, the negative effects were observed when the average values of SAC tended to increase, approaching the limit value of $0.34 \mathrm{~m}^{3} \mathrm{~m}^{-3}$. According to Sojka (1992) and Klein et al. (2008), there are many negative effects that an imbalanced SAC could have on plants, mainly because they act directly on plant physiology, with emphasis on stomatal closure, plant wilting, root necrosis, obstruction to xylem water flow and nutritional and hormonal imbalance in plants.

Figure 4 (b) shows an extremely weak negative correlation between TP x DMP (-0.016). It is emphasized through this result, that total porosity is not a limiting factor to the shoot dry matter production in grasses. The mean values were in the range of 0.45 to $0.50 \mathrm{~m}^{3} \mathrm{~m}^{-3}$, so we can consider it suitable for good soil operation. 


\section{Al Macrothink}

The lack of response of grasses to TP is explained by the fact that this variable is composed of a sum of numerous pore classes, such as macroporosity, microporosity, aeration porosity, bioporosity, cryptoporosity, among others. And as shown in Figure 4 ( $a$ and b), the behavior of microporosity and macroporosity are divergent on dry matter production, thus reflecting on the low representativeness of TP on the DMP variable.

Total soil porosity is vital for soil functioning in the physical, chemical and biological realms, however, Klein \& Libardi (2002) and Silva et al. (2017b) point out that the importance of this attribute is not only in its volume, but also in the way pores are distributed in the diameter, becoming a key factor in soil fertility and crop productivity, as it interferes with factors such as drainage, available water content to plants, nutrient absorption, root penetration, aeration and temperature.

Figure 5 (a) shows the results of the correlation analysis between available water content $\left(\theta_{\mathrm{AWC}}\right)$, (b) field capacity $\left(\theta_{\mathrm{FC}}\right)$ and (c) permanent wilting point $\left(\theta_{\mathrm{PWP}}\right)$, with the dry matter production of grasses.
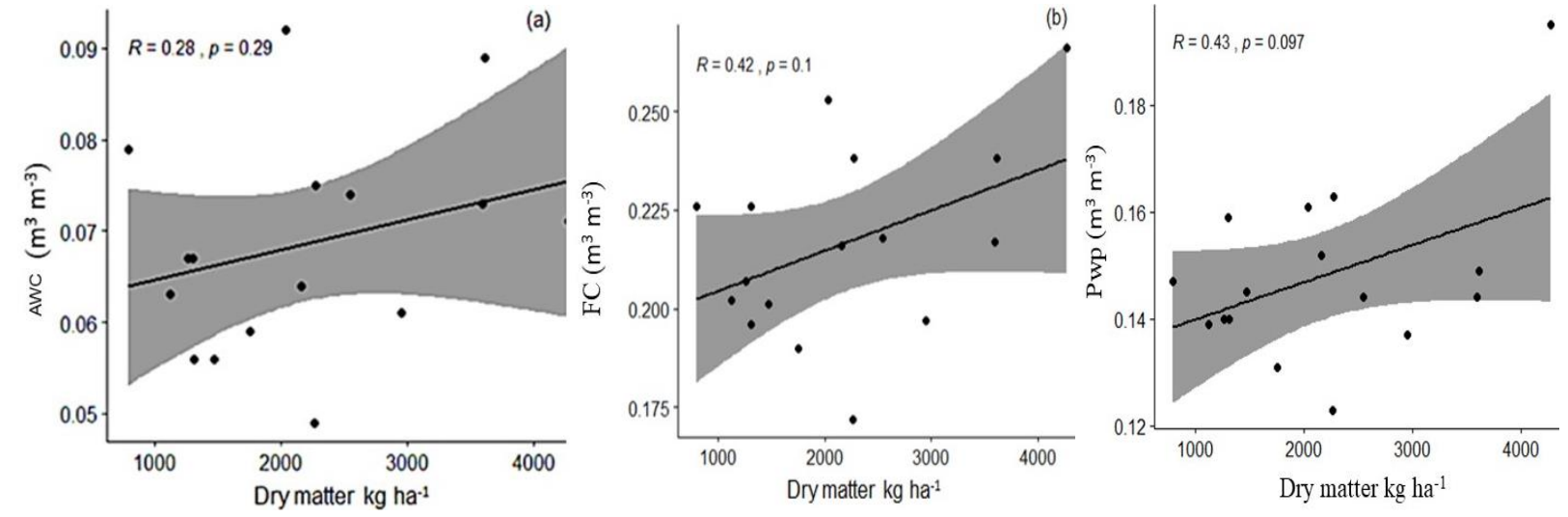

Figure 5. Linear correlation of available water content (a), field capacity (b) and permanent wilting point (c) with shoot dry matter production (DMP) in grasses of Brachiaria genus

Positive linear correlation values between $\theta_{\mathrm{AWC}} \times \mathrm{DMP}(R=0.28, p=0.29), \theta_{\mathrm{FC}} \times \mathrm{DMP}(R=$ $0.42, p=0.10)$ and $\theta_{\mathrm{PWP}} \times \mathrm{DMP}(R=0.43, p=0.097)$ are noted. $\theta_{\mathrm{AWC}}$ presented a weak positive correlation, but $\theta_{\mathrm{FC}}$ and $\theta_{\mathrm{PWP}}$ presented moderate correlation with grass dry matter production, demonstrating its importance for plant development.

Although the statistical analysis did not show significant correlation values between these attributes and DMP, it is emphasized that there was a mutual increase in DMP and the mean values of $\theta_{\mathrm{AWC}}, \theta_{\mathrm{FC}}$ and $\theta_{\mathrm{PWP}}$ (Figure $5 \mathrm{a}, \mathrm{b}, \mathrm{c}$ ). Water retained in the subsurface layers of the soil possibly favored the maintenance of dry matter production by grasses, because they have an abundant root system and so they are able to absorb promptly available water from deeper soil layers.

And despite the water restriction imposed by the soil, it is observed that available water content values in the 0.05 to $0.09 \mathrm{~m}^{3} \mathrm{~m}^{-3}$ range, were not restrictive to grass dry matter production (Figure 5). Pezzopane et al. (2015), evaluating Brachiaria brizantha response mechanisms to 
water stress, observed that there was a reduction in biomass production and leaf area, as well as an increase in the number of roots in deeper soil layers, as a function of soil moisture reduction.

It is estimated that fifty percent of the total water volume retained in the soil (available water content), is readily available to plants. In this case it can be stated that the grass species Brachiaria decumbens Stapf., Brachiaria brizantha (Hochst) Stapf., Brachiaria humidicola (Rendle) Schwnickerdt Vr. and Brachiaria brizantha MG5 cv. Vitória, maintain a linear increase in dry matter production, even with low water content in the soil (Figure 5, a, b and c). For Aspiazú et al. (2010), the biomass production in water-restricted grasses occurs due to their metabolism (C4), being therefore efficient in water use.

Saturated hydraulic conductivity $\left(\mathrm{K}_{\theta}\right)$ showed a weak negative correlation with grass dry matter production $(R=-0.37, p=0.16)$. It can be observed (Figure 6) a decreasing linear correlation with DMP as saturated hydraulic conductivity increases.

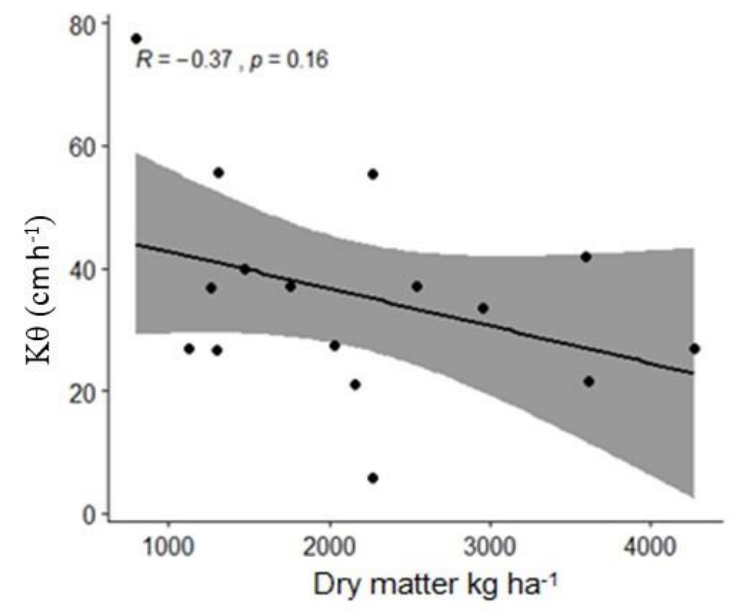

Figure 6. Linear correlation of saturated hydraulic conductivity with shoot dry matter production (DMP) in grasses of Brachiaria genus

The average values of saturated hydraulic conductivity were between 0 to $80 \mathrm{~cm} \mathrm{~h}^{-1}$ with strong data dispersion in relation to the main line. It can be observed in Figure 6 that the minimum value of dry matter production was pronounced when $\left(\mathrm{K}_{\theta}\right)$ approached $40 \mathrm{~cm} \mathrm{~h}^{-1}$, indicating that, although beneficial, water in large volumes may compromise development and productivity of grasses.

From all evaluated attributes, it is observed that the most representative negative correlation value was observed for $\mathrm{K}_{\theta} \mathrm{x} \mathrm{DMP}=-0.37$ (Figure 6). Several factors are involved in this result, as saturated hydraulic conductivity depends on soil texture and porosity, especially macroporosity (Mesquita \& Moraes, 2004). This result suggests that saturated hydraulic conductivity was favored by increased soil macroporosity (Figure 2b) and both attributes were negatively correlated with grass dry matter production.

Therefore, it can be affirmed that the increase in porous spaces larger than $0.05 \mathrm{~mm}(\mathrm{Ma})$ increases the aeration capacity of the soil and reduces the contact surface of the roots with the soil solution, compromising the absorption of nutrients, which sometimes accumulate in the 
subsurface layers of the soil. This may reduce the response of grasses to dry matter production due to the large volume of voids and smaller contact surface at the root-soil-solution interface, where water and nutrients are contained. Hara et al. (2019) observed a reduction in hydraulic conductivity with an increase in the root system of Urochloa brizantha. According to them, the reduction in $\mathrm{K}_{\theta}$ is due to the fact that, with the increase of the root system, there is a consequent reduction in the soil macroporosity, which increases again after the root system dries out.

Figure 7, shows linear correlation values of mean weighted diameter of dry (a) and wet (b) aggregates and of aggregates stability index (c) with shoot dry matter production in grasses.
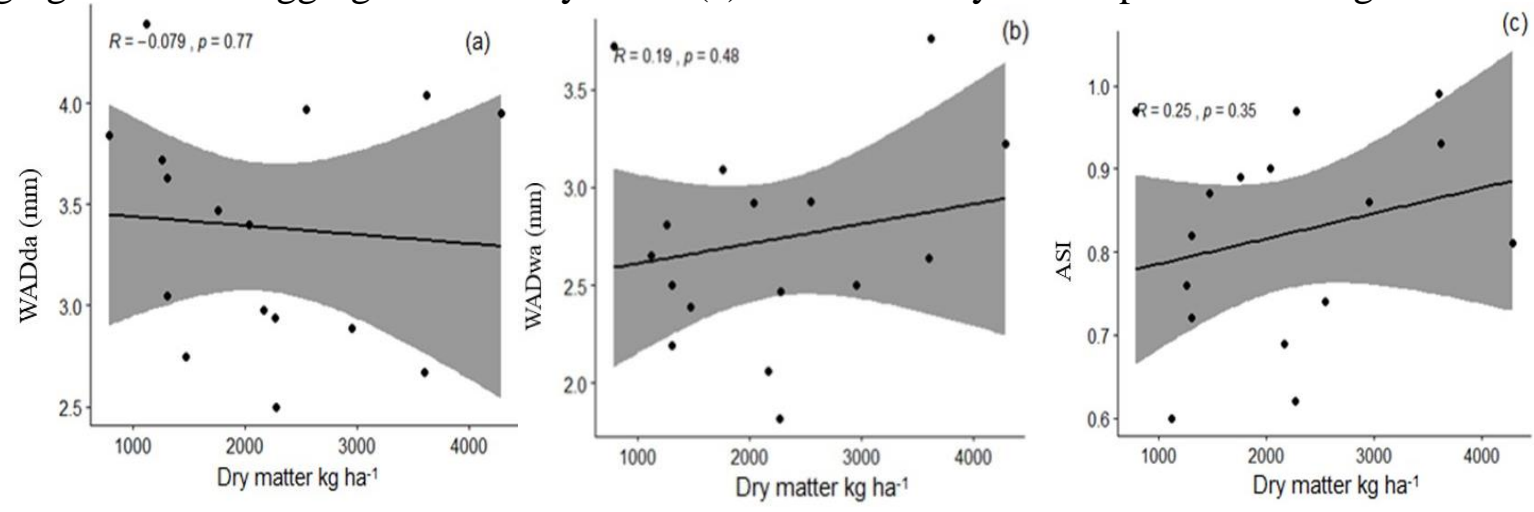

Figure 7. Linear correlation of Wet MWD (a), Dry MWD (b) and ASI (c) with shoot dry matter production (DMP) in grasses of Brachiaria genus

There was a weak negative correlation between the mean weighted diameter of dry aggregates (Dry MWD) and grass shoot dry matter production (DMP) $(R=-0.079, p=0.77)$ and diameter values ranged from 2.5. to $4.0 \mathrm{~mm}$. Mean weighted diameter of wet aggregates (Wet MWD), showed a weak positive correlation with DMP $(R=0.19, p=0.48)$ and the mean diameter values ranged from 2.0 to $3.5 \mathrm{~mm}$.

For the aggregate stability index (ASI), it was observed that there was a weak positive correlation with DMP $(R=0.25, p=0.35)$ and mean values ranged from 0.6 to 1.0. With the exception of Wet MWD, the other attributes (Dry MWD and ASI) positively favored dry matter production as their mean values increased (Figure 7, b and c). Regarding the ASI, the mean values between 0.6 and 1.0 indicate that the evaluated soil presents an adequate degree of stability, having a positive effect on the DMP. Wet MWD and ASI are used as soil quality indicators, for predicting possible structural disturbances and their positive correlation with DMP confirm that soil conservation is essential for plant development, being related mainly to root development and shoot production.

High aggregate stability is essential for plant establishment, especially in terms of diameter, as it has a strong influence on the development of the root system, which under unfavorable conditions loses the ability to penetrate the intra-aggregate pores (Camargo \& Alleoni, 2006). Soils with a high aggregate stability index favor the establishment and development of the root system of plants, reflecting on the green and dry matter production of grasses. And as there is a direct relationship between the roots of plants and the formation of aggregates (Salton et al. 2008), it is clear that over time there is a balance within the system, where the 
input of organic matter is sufficient for the production of dry matter.

Preservation of soil physical attributes, especially aggregates, is an efficient way to generate straw, allowing greater mulching over the soil (Silva et al., 2011b). In addition, there is a direct relationship between leaf area and soil root volume, which in grassy pasture areas contributes to aggregate formation (Salton et al., 2008) and improvements in structure and other emerging properties of the soil (Mielniczuk et al., 2003).

Thus, it can be affirmed that the high production of dry matter by grasses is directly correlated with the physical attributes of soil quality, especially those related to soil water availability. Table 3 shows the average values of the soil physical attributes that were used to evaluate the correlation with shoot dry matter production in grasses.

Table 3. Significance level, mean and correlation values for physical variables correlated with grass shoot dry matter production

\begin{tabular}{|c|c|c|c|c|}
\hline Variable & Unit & Mean Value & $\boldsymbol{R}$ & $p$ \\
\hline $\mathrm{TP}$ & \multirow{7}{*}{$\mathrm{m}^{3} \mathrm{~m}^{-3}$} & 0.47 & -0.16 & 0.95 \\
\hline $\mathrm{Ma}$ & & 0.14 & -0.24 & 0.37 \\
\hline $\mathrm{Mi}$ & & 0.32 & 0.23 & 0.39 \\
\hline$\theta_{\mathrm{FC}}$ & & 0.216 & 0.42 & 0.10 \\
\hline$\theta_{\mathrm{PWP}}$ & & 0.148 & 0.43 & 0.097 \\
\hline$\theta_{\text {AWC }}$ & & 0.068 & 0.28 & 0.29 \\
\hline SAC & & 0.25 & -0.24 & 0.36 \\
\hline $\mathrm{BD}$ & $\mathrm{g} \mathrm{cm}^{-3}$ & 1.18 & 0.13 & 0.64 \\
\hline $\mathrm{CD}$ & $\%$ & 64.25 & 0.13 & 0.64 \\
\hline \multirow[t]{2}{*}{ Wet MWD } & \multirow{3}{*}{$\mathrm{mm}$} & 2.73 & 0.19 & 0.48 \\
\hline & & & & \\
\hline Dry MWD & & 3.38 & -0.079 & 0.77 \\
\hline ASI & ---------- & 0.807 & 0.25 & 0.36 \\
\hline $\mathrm{K}_{\theta}$ & $\mathrm{cm} \mathrm{h}^{-1}$ & 35.65 & -0.37 & 0.16 \\
\hline
\end{tabular}

Wet $\mathrm{MWD}=$ Mean weighted diameter of wet aggregates; Dry MWD = Mean weighted 
diameter of dry aggregates; ASI = Aggregates stability index; $\theta_{\mathrm{FC}}=$ Field capacity; $\theta_{\mathrm{PWP}}=$ Permanent wilting point; $\theta_{\mathrm{AWC}}=$ Available water content; $\mathrm{K}_{\theta}=$ Saturated hydraulic conductivity; $\mathrm{TP}=$ Total porosity; $\mathrm{Ma}=$ Macroporosity; $\mathrm{Mi}=$ Microporosity; $\mathrm{SAC}=$ Soil aeration capacity $\mathrm{BD}=$ Bulk density $\mathrm{CD}=$ Compaction degree; $R=$ Correlatio value; $p=$ Significance value.

Favorable attributes to dry matter production in grasses include bulk density, compaction degree, microporosity, available water content, field capacity, permanent wilting point, mean weighted diameter of wet aggregates and aggregate stability index (Table 3). The attributes that negatively influenced dry matter production were macroporosity, soil aeration capacity, saturated hydraulic conductivity and mean weighted diameter of dry aggregates.

The total soil porosity had almost no effect on the shoot dry matter production of grasses (Table 3 ). The positive variables that most influenced DMP were $\theta_{\mathrm{FC}}=0.42$ and $\theta_{\mathrm{PWP}}=0.43$; and the most representative negative value in relation to DMP was $\mathrm{K}_{\theta}=-0.37$ (Table 3).

\section{Conclusion}

Grass shoot dry matter production decreases with increases in the average values of macroporosity, soil aeration capacity, saturated hydraulic conductivity and mean weighted diameter of dry aggregates.

The increase in the average values of bulk density, compaction degree, microporosity, available water content, field capacity, permanent wilting point, mean weighted diameter of wet aggregates and aggregate stability index favored the increase in shoot dry matter production of grasses.

\section{References}

Almeida, D. J., Silva, I. F., Silveira, F. P. M., Santiago, R. D., \& Costa, J. R. C. (2014). Poaceae cespitosa e decumbente adubadas com NPK: Efeitos na agregação do solo. Pesquisa Agropecuária Tropical, 44, 50-55. https://doi.org/10.1590/S1983-40632014000100002

Aspiazú, I., Sediyama, T., Ribeiro J. R. J. I., Silva, A. A., Concenco, G., Ferreira, E. A., ... Araujo, W. F. (2010). Eficiência do uso da água de plantas de mandioca em condições de competição. Planta Daninha, 28, 699-703.

https://doi.org/10.1590/S0100-83582010000400001

Assis, P. C. R., Stone, I. F., Medeiros, J. C., Madari, B. E., Oliveira, J. M., \& Wruck, F. S. (2015). Atributos físicos do solo em sistemas de integração Lavoura-Pecuária-Floresta. Revista Brasileira de Engenharia Agrícola e Ambiental, 19, 309-316. https://doi.org/10.1590/1807-1929/agriambi.v19n4p309-316

Associação Brasileira das Indústrias Exportadoras de Carne-ABIEC. (2018). Perfil da pecuária no Brasil: Relatório anual.

https://abiec.siteoficial.ws/images/upload/sumario-pt-010217.pdf (Acessed July 30 2019)

Barros, K. R. M., Lima, H. V., Rodrigues, S., \& Kern, D. C. (2016). Distribuição da porosidade textural e estrutural em solos de Terra Preta Arqueológica. Revista Ciência 
Agronômica, 47, 609-615. https://doi.org/10.5935/1806-6690.20160073

Blake, G.R., \& Hartge, K. H. (1986). Bulk density. In: Klute, A. (Ed.), Methods of Soil Analysis: I. Physical and Mineralogical Methods. (1st ed.). Madison: American Society of Agronomy p. 425-442. https://doi.org/10.2136/sssabookser5.1.2ed.c13

Camargo de, O. A., \& Alleoni, L. R. F. (2006). Efeito da compactação no crescimento de plantas. https://www.infobibos.com/Artigos/2006_2/C5/Index.htm. (Acesso em: 29 Jul. 2019).

Carpenedo, V., \& Mielniczuk, J. (1990). Estado de agregação e qualidade de agregados de Latossolos Roxos, submetidos a diferentes sistemas de manejo. Revista Brasileira de Ciência do Solo, 14, 99-105.

Dexter, A. R. (2004). Soil physical quality. Part I. Theory, effects of soil texture, density and organic matter, and effects on root growth. Geoderma, 120, 201-214.

https://doi.org/10.1016/j.geoderma.2003.09.004

Dias-Filho, M. (2014). Diagnóstico das pastagens no Brasil. Belém: Embrapa, 38 p. (Doc. N. 402). https://www.infoteca.cnptia.embrapa.br/bitstream/doc/986147/1/DOC402.pdf

Ferreira, G. C. V., \& Ferreira Neto, J. A. (2018). Usos de geoprocessamento na avaliação de degradação de pastagens no assentamento Ilha do Coco, Nova Xavantina - Mato Grosso, Brasil. Revista Engenharia na Agricultura, 26, 140-148.

https://doi.org/10.13083/reveng.v26i2.894

Foloni, J. S. S., Calonego, J. C., \& Lima, S. L. (2003). Efeito da compactação do solo no desenvolvimento aéreo e radicular de cultivares de milho. Pesquisa Agropecuária Brasileira, 38, 947-953. https://doi.org/10.1590/S0100-204X2003000800007

Hara, A. T., Domingues, J. V. S., Gonçalves, A. C. A., Santos, F. A. S., Hashiguti, H. T., \& Rezende, R. (2019). Condutividade hidráulica em função do crescimento de Urochloa decumbens. Revista Brasileira de Agricultura Irrigada, 13, 3454-3466.

https://doi.org/10.7127/RBAI.V13N301073

Kemper, W. D., \& Chepil W. S. (1965). Size distribution of aggregates. In C. A. Black (Ed.), Methods of soil analysis (1st ed., pp. 499-510). Madison: American Society of Agronomy.

Klein, V. A., \& Libardi, P. L. (2002). Densidade e distribuição do diâmetro dos poros de um latossolo vermelho, sob diferentes sistemas de uso e manejo. Revista Brasileira de Ciência do Solo, 26, 857-867. https://doi.org/10.1590/S0100-06832002000400003

Klein, V. A., Vieira, M. L., Durigon, F. F., Massing, J. P., \& Fávero, F. (2008). Porosidade de aeração de um Latossolo Vermelho e rendimento de trigo em plantio direto escarificado. Ciência Rural, 38, 365-371. https://doi.org/10.1590/S0103-84782008000200011

Labegalini, N. S., Damião, F. N., \& Andrade, L. (2016). Desenvolvimento da cultura do milho sob efeitos de diferentes profundidades de compactação do solo. Revista de Agricultura Neotropical, 3, 7-11. https://doi.org/10.32404/rean.v3i4.1102 
Leonel, C. L., Freddi, D. S., Beutler, A. N., Centurion, M. A. D. C., \& Centurion, J. F. (2007). Influência do Solo no crescimento radicular e na produtividade do amendoim. Científica, 35, 51-60. http://cientifica.org.br/index.php/cientifica/article/view/174

Lima, J. R. S., Souza, E. S., Antonino, A. C. D., Silva, I. F., Corrêa, M. M., \& Lira, C. A. B. O. (2014). Atributos físico-hídricos de um Latossolo Amarelo cultivado e sob mata nativa no brejo paraibano. Revista Brasileira de Ciências Agrárias, 9, 599-605.

https://doi.org/10.5039/agraria.v9i4a3532

Lima, R. P., Leon, M. J., \& Silva, A. R. (2013). Compactação do solo de diferentes classes texturais em áreas de produção de cana-de-açúcar. Revista Ceres, 60, 6-20.

https://doi.org/10.1590/S0034-737X2013000100003

Macedo, M. C. M., Zimmer, A. H., \& Kichel, A. N. (2000). Degradação e alternativas de recuperação e renovação de pastagens. (1st ed.). Campo Grande: Embrapa Gado de Corte, p. 4. (Comunicado Técnico, 62).

Mazurana, M., Fink, J. R., Silveira, V. H., Levien, R., Zulpo, L., \& Brezolin, D. (2013). Propriedades físicas do solo e crescimento de raízes de milho em um Argissolo vemelho sob tráfego controlado de máquinas. Revista Brasileira de Ciência do Solo, 37, 1185-1185. https://doi.org/10.1590/S0100-06832013000500008

Mesquita, M. G. B. F., \& Moraes, S. O. (2004). A dependência entre a condutividade hidráulica saturada e atributos físicos do solo. Ciência Rural, 34, 963-969.

https://doi.org/10.1590/S0103-84782004000300052

Mielniczuk, J., Bayer, C., Vezzani, F., Lovato, T., Fernandes, F. F. \& Debarba, L. (2003). Manejo de solo e culturas e sua relação com estoques de carbono e nitrogênio do solo. In: Curi, N., Marques, J. J., Guilherme, L. R. G., Lima, J. M., Lopes, A. S. S. \& Alvarez, V. V. H. (eds.). Tópicos em ciência do solo. (3st ed.). Viçosa: Sociedade Brasileira de Ciência do Solo. p. 209-248.

Nascimento, D. M., Cavalieri-Polizeli, K. M. V., Silva, A. H., Favaretto, N., \& Parron, L. M. (2019). Soil physical quality under long-term integrated agricultural production systems. Soil \& Tillage Research, 186, 292-299. https://doi.org/10.1016/j.still.2018.08.016

Pezzopane, C. G., Santos, P. M., Cruz, P. G., Altoé, J., Ribeiro, F. A., \& Valle, C. B. do. (2015). Estresse por deficiência hídrica em genótipos de Brachiaria brizantha. Ciência Rural, 45, 871-876. https://doi.org/10.1590/0103-8478cr20130915

R Development Core Team. (2013). R: A language and environment for statistical computing. Vienna: R Foundation for Statistical Computing. Retrieved from https://www.r-project.org

Reichert, J. M., Suzuki, L. E. A. S., Reinert, D. J. (2007). Compactação do solo em sistemas agropecuários e florestais: Identificação, efeitos, limites críticos e mitigação. In: Ceretta, C. A., Silva, L. S., Reichert, J. M. (Eds.) Tópicos em ciência do solo. (5st ed.). Viçosa: Sociedade Brasileira de Ciência do Solo, p. 49-134.

Reynolds, W. D., Bowman, B. T., Drury, C. F., Tan, C. S., \& Lu, X. (2002). Indicators of good soil physical quality: Density and storage parameters. Geoderma, 110, 131-146. 
https://doi.org/10.1016/S0016-7061(02)00228-8

Reynolds, W. D., Drury, C. F., Yang, X. M., Fox, C. A., Tan, C. S.; Zhang, T. Q. (2007). Land management effects on the near-surface physical quality of a clay loam. Soil and Tillage Research, 96, 316-330. https://doi.org/10.1016/j.still.2007.07.003

Richart, A., Tavares Filho, J., Brito, O. R., Llanillo, R. F., \& Ferreira, R. (2005). Compactação de solo: Causas e efeitos. Semina: Ciências Agrárias, 26, 321-344. https://doi.org/10.5433/1679-0359.2005v26n3p321

Rolim, G. S., Sentelhas, P. C., \& Barbieri, V. (1998). Planilhas no ambiente Excel ${ }^{\mathrm{TM}}$ para os cálculos de balanços hídricos: Mensal sequencial, de cultura e de produtividade real e potencial. Revista Brasileira de Agrometeorologia, 6, 133-137.

https://coral.ufsm.br/rba/t13313761.html.

Rosa, H. A., Fontana, W. C., \& Resende, J. D. (2019). Desenvolvimento inicial do trigo em diferentes densidades de solo. Revista Técnico-Científica do CREA-PR, 19, 1-10. https://creaprw16.crea-pr.org.br/revista/Sistema/index.php/revista/article/view/541/327

Salton, J. C., Mielniczuk, J., Bayer, C., Boeni, M., Conceição, P. C., Fabrício, A. C., Macedo, M. C. M., \& Broch, D. L. (2008). Agregação e estabilidade de agregados do solo em sistemas agropecuários em Mato Grosso do Sul. Revista Brasileira de Ciência do Solo, 32, 11-21. https://doi.org/10.1590/S0100-06832008000100002

Santos, H. G. et al. (2018). Sistema Brasileiro de Classificação de Solos. (5st ed.) Brasília: Empresa Brasileira de Pesquisa Agropecuária, p. 590.

Santos, P. M., Cruz, P. G. da., Araújo, L. C., Pezzopane, J. R. M., Valle, C. B. do. \& Pezzopane, C. G. (2013). Response mechanisms of Brizantha cultivars to water deficit strees. Revista Brasileira de Zootecnia, 42, 767-773.

https://doi.org/10.1590/S1516-35982013001100001

Silva, D. A., Souza, L. C., Vitorinio, A. C. T. F., \& Gonçalves, M. C. (2011). Aporte de fitomassa pelas sucessões de culturas e sua influência em atributos físicos do solo no sistema plantio direto. Bragantia, 70, 147-156. https://doi.org/10.1590/S0006-87052011000100021

Silva, I. F., \& Mielniczuk, J. (1997). Ação do sistema radicular de plantas na formação e estabilização de agregados do solo. Revista Brasileira de Ciência do Solo, 21, 113-117. https://doi.org/10.1590/ S0100-06831997000300012

Silva, L. E., Alquerque, U. P., \& Amaral, W. (2017). Uso sustentável da biodiversidade e conservação de recursos naturais. Guaju, 3, 2-10. https://doi.org/10.5380/guaju.v3i1.53845

Silva, P. L. F., Oliveira, F. P., Pereira, W. E., Borba, J. O. M., Tavares, D. D., Santos, T. E. D., \& Martins. A. F. (2019). Estoques de carbono e retenção hídrica em biomassa de gramíneas no agreste da Paraíba. Brazilian Journal of Biossystems Engineering, 13, 155-167. https://doi.org/10.18011/bioeng2019v13n2p155-167

Silva, R. F., Guimarães, M. F., Aquino, A. M., \& Mercante, F. M. (2011). Análise conjunta de atributos físicos e biológicos do solo sob sistema de integração lavoura-pecuária. Pesquisa 
Agropecuária Brasileira, 46, 1277-1283.

https://doi.org/10.1590/S0100-204X2011001000023

Silva, R. O., Barioni, L.G., Hall, J. A. J., Moretti, A. C., Veloso, R. F., Alexander, P., Crespolini, M., Moran, D. (2017). Sustainable intensification of Brazilian livestock production through optimized pasture restoration. Agricultural Systems. 153, 201-211.

https://doi.org/10.1016/j.agsy.2017.02.001

Sojka, R. E. (1992). Stomatal closure in oxygen-stressed plants. Soil Science Society of America Journal, 154, 269-280. https://doi.org/10.1097/00010694-199210000-00003

Suzuki, L. E. A. S, Reichert, J. M., Reinert, D. J., \& Lima, C. L. R. (2007). Grau de compactação, propriedades físicas e rendimento de culturas em Latossolo e Argissolo. Pesquisa Agropecuária Brasileira, 42, 1159-1167.

https://doi.org/10.1590/S0100-204X2007000800013

Teixeira, P. C., Donagemma, G. K., Fontana, A., Teixeira, W. G. (eds.). (2017). Manual de métodos de análise de solo. (3st ed.). Brasília, Empresa Brasileira de Pesquisa Agropecuária, p. 573.

Tormena. C. A., Barbosa, M. C., Costa, A. C. S., \& Gonçalves, A. C. A. (2002). Densidade, porosidade e resistência à penetração em Latossolo cultivado sob diferentes sistemas de preparo do solo. Scientia Agricola, 59, 795-801.

https://doi.org/10.1590/S0103-90162002000400026

Valadão, F. C. A., Weber, D. L. S., Valadão Júnior, D, D., Scapinelli, A., Deina, F. R., \& Bianchini, A. (2015). Adubação fosfatada e compactação do solo: Sistema radicular da soja e do milho e atributos físicos do solo. Revista Brasileira de Ciência do Solo, 39, 243-255. https://doi.org/10.1590/01000683rbcs20150144

Valadão, F. C. A., Weber, D. L. S., Valadão Júnior, D. D., Santini, M. F. M., \& Scapinelli, A. (2017). Teor de macronutrientes e produtividade da soja influenciadas pela compactação do solo e adubação fosfatada. Revista de Ciências Agrárias, 40, 183-195.

https://doi.org/10.19084/RCA15092

Vitória, E. L., Fernandes, H. C., Teixeira, M. M., Cecon, P. R., Lacerda, E. G. (2012). Correlação linear e espacial entre produtividade de Brachiaria brizantha, densidade do solo e porosidade total em função do sistema de manejo do solo. Engenharia Agrícola, 2, 909-919. https://doi.org/10.1590/S0100-69162012000500010

\section{Copyright Disclaimer}

Copyright for this article is retained by the author(s), with first publication rights granted to the journal.

This is an open-access article distributed under the terms and conditions of the Creative Commons Attribution license (http://creativecommons.org/licenses/by/4.0/). 